\title{
Influence of Land Configuration, Irrigation Level and Nutrient Management on Yield and Quality of Turmeric
}

\author{
H. H. Dikey ${ }^{\text {** }}$, V. M. Bhale ${ }^{2}$, V. S. Kale ${ }^{3}$ and R. S. Wankhade ${ }^{4}$ \\ ${ }^{1}$ Regional Research Centre, Dr. Panjabrao Deshmukh Krishi Vidyapeeth, \\ Amravati- 444603, Mahrashtra, India \\ ${ }^{2}$ Dr. Panjabrao Deshmukh Krishi Vidyapeeth, Akola, Mahrashtra, India \\ ${ }^{3}$ Department of Vegetable Science, Dr. Panjabrao Deshmukh Krishi Vidyapeeth, \\ Akola, Mahrashtra, India \\ ${ }^{4}$ Agriculture Research Station, Dr. Panjabrao Deshmukh Krishi Vidyapeeth, \\ Achalpur Dist. Amravati-Mahrashtra, India \\ *Corresponding author
}

\section{Keywords}

Organic manures, Curcuma longa L., rhizome yield, curcumin, oleoresin and curing

Article Info

Accepted:

22 August 2019 Available Online: 10 September 2019

A field experiment was carried out during kharif season of the year 2014-15 and 2015-16 at the Research Farm, Department of Agronomy, Dr. Panjabrao Deshmukh Krishi Vidyapeeth, Akola (Maharashtra) to study the effect of land configuration, irrigation level and nutrient management on yield and quality of turmeric (Curcuma longa L.). A set of twenty four treatment combinations of land configuration, irrigation level and nutrient management $(2 \times 3 \times 4)$ were laid out in a Split plot design with three replications. The experimental results revealed that total yield of turmeric $\mathrm{ha}^{-1}$ and yield of cured fingers $\mathrm{ha}^{-1}$, were recorded significantly superior in broad bed furrow of land configuration, irrigation level $40 \mathrm{~mm}$ CPE (I1), application of $100 \% \mathrm{RDF}+25 \% \mathrm{RDN}$ through vermicompost and treatment combination $40 \mathrm{~mm}$ CPE with $100 \%$ $\mathrm{RDF}+25 \% \mathrm{RDN}$ through vermicompost. The curcumin, oleoresin and curing percent did not influenced due to different land configuration treatments whereas irrigation level $40 \mathrm{~mm} \mathrm{CPE}$, application of $100 \% \mathrm{RDF}+25 \% \mathrm{RDN}$ through vermicompost and treatment combination $40 \mathrm{~mm}$ CPE with $100 \%$ $\mathrm{RDF}+25 \% \mathrm{RDN}$ through vermicompost were significantly higher as compare to other treatments.

\section{Introduction}

India is the largest producer of turmeric in the world. Turmeric (Curcuma longa L.) is one of the second most important spice crops in foreign exchange earnings after chilli. Turmeric contains curumin (diferuloylmethene) (3-4\%) is responsible for the yellow colour and its comprised of curcumin I (94\%) and curcumin II (6\%) and 
curcumin III (0.3\%) (Ruby et al., 1995). The use of turmeric dates back nearly 4000 years, to the Vedic culture in India where it was used a culinary spice and had a religious significance.

Turmeric is used as coloring matter in pharmacy, confectionary and food industry (Purseglove et al., 1981). Turmeric oil and oleoresin are also used to impart flavor in food and perfume industries. The major quantity of turmeric is utilized as condiment and a small quantity is used in medicines and cosmetics in India. The antibacterial effect of turmeric is due to three principal compounds viz. curcumin, curcuminoids and aromatic oil, out of which, curcumin is the most active therapeutic ingredient. Curcumin is now being used to treat cancer, arthritis, diabetes, Crohn's disease, cardiovascular diseases, osteoporosis, Alzheimer's disease, psorosis and other pathologies (Shishodia, 2005). Thus both turmeric and curcumin have potential for the development of modern medicines for the treatment of various diseases. Due to its increasing demand, not only for internal consumption but for export purpose also, the productivity and quality of crop needs to be upgraded (Medhi and Bora, 1993).

Land configuration helps for maximizing rainfall infiltration, minimizing erosion, total runoff, facilitates drainage and ultimately improves water use efficiency. The raised bed zone of broad bed and furrow system is better aerated with lower penetration resistance and favourable for deeper seed placement and better crop emergence (Jayapaul et al., 1996). Land configuration, which involves different methods of seed bed preparations, is one of the most important management practices which increases input use efficiency and crop production.

Water and fertilizer are the two important inputs for agricultural production and are interrelated in their effects on plant growth and yield. In addition to the total quantity of water, availability of water at different stages of the plant growth can also affect the yield and quality of the crop. Inadequate moisture during the growth and development stage results not only in lower yields but also in poor quality.

Turmeric has a high demand for plant nutrients and generally responds to applied nutrients for yield \& quality. The quantity of fertilizers (inorganic or organic) required by the crop depend on the variety as well as soil, and weather conditions prevailing during crop growth (Karthikeyan et. al., 2009). Soil fertility levels are maintained to match with crop's need and in proper proportions then crop productivity measured in terms of responses to fertilizers can only be sustained.

Turmeric is commercially cultivated however, the production of turmeric per unit land area in vidarbha is very low because of the poor knowledge on improved cultivation technology to the farmers. Considering the all above facts, the present investigation is therefore planned to study the effect of land configuration, irrigation level and nutrient management on yield and quality of turmeric.

\section{Materials and Methods}

A field experiment was carried out at the Research Farm, Department of Agronomy, Dr. Panjabrao Deshmukh Krishi Vidyapeeth, Akola (Maharashtra) during kharif season of the year 2014-15 and 2015-16. A set of twenty four treatment combinations of land configuration, irrigation level and nutrient management $(2 \times 3 \times 4)$ were laid out in a Split plot design with three replications. The Turmeric crop (variety - PDKV Waigaon) was raised using nutrient dose @ RDF 200:100:100 Kg NPK per hectare. Nitrogen, Phosphorus and Potassium were applied in the 
form of urea, single super phosphate and muriate of potash respectively. The fertilizers as per treatments were applied at the spot of planting in rings and were thoroughly mixed in the soil with the help of weeding hook. Vermicompost was applied to different treatment plots. A seed rhizome was planted at $10 \mathrm{~cm}$ depth in the center of ridge in ridges and furrow method and three lines were planted on broad bed furrow at given spacing of $45 \mathrm{~cm} \mathrm{X} 22.5 \mathrm{~cm}$ at the rate of 25 quintal $\mathrm{ha}^{-1}$. At the time of planting mother rhizomes were treated with Carbendenzim 50 WP @ $1 \mathrm{gm}+$ Quinalphos $2 \mathrm{ml} / \mathrm{l}$ for 30 minutes. The irrigation system of pvc pipes consisted of main and sub-main of 75,63 and $50 \mathrm{~mm}$ diameter were laid in each plot for irrigation. Control valves were fixed on main and submain pipeline. Water meter was fixed on main pipeline for measuring the discharge of water during the irrigation. Measured quantity of water was applied to each plot. During the year 2014-15, total 15, 10 and 08 irrigations were given to 40, 60 and $80 \mathrm{CPE}$ irrigation levels where as 19, 14 and 10 irrigations were applied to 40, 60 and $80 \mathrm{CPE}$ irrigation levels respectively in the year 2015-16

The depth of each irrigation was $10 \mathrm{~cm}$ in case of ridges and furrow and broad bed furrow planting. Earthing up, weedicide application and plant protection measures were undertaken as per recommendation in the experimental area. The crop was harvested at full physiological maturity. Five plants in each treatment per replication were tagged randomly for recording the observations on yield and quality parameters and mean values were subjected to statistical analysis. For quality analysis, rhizomes harvested from each treatment were boiled in pure water till rhizomes become soft and emit a typical turmeric odour after boiling. Then the rhizomes were dried under sun for about 8-10 days till consecutive weights agreed before grinding them in a mill. These powdered samples were analysed for curcumin and oleoresin content. The oleoresin content was estimated as per the procedure given by Ranganna (1986). Procedure suggested by Manjunath et al., (1991) was followed for the estimation of curcumin content. Curing percentage of the rhizomes was recorded by weight of cured rhizome divided by fresh weight of the rhizome. Data collected during the course of investigation ware statistically analyzed by adopting standard procedure of 'Analysis of Variance' by Panse and Sukhatme (1967). Biometric observations recorded during the course of investigation along with sample size and recording time. The data on yield and quality were taken on total yield of turmeric (Mother + Primary+ Secondary) $\mathrm{ha}^{-1}$, oleoresin, curcumin and curing percentage.

\section{Results and Discussion}

\section{Effect of land configuration on yield}

The fresh rhizomes yield and yield of cured fingers of turmeric were significantly influenced due to land configuration (Table 1). Broad bed furrow method of planting recorded significantly highest total fresh rhizomes yield of turmeric (227.43, 270.93 and $249.18 \mathrm{q} \mathrm{ha}^{-1}$ ) and yield of cured fingers $\mathrm{ha}^{-1}(30.08,40.20$ and $35.14 \mathrm{q} \mathrm{ha}^{-1}$ ) over the ridges and furrow planting during the year 2014 and 2015 respectively. (Table 1). The results corroborate the earlier findings of Gill et al., (2009).

Better soil physical properties also provide favourable condition for development of rhizome. Similarly, Jayashree and Rao (2002) reported that land layout broad bed furrow (BBF) was the better practice in Vertisols than flat bed as the per cent age of transmission pores were more in BBF bed system. It is thus evident that broad bed furrow planting was superior over ridges and furrow method for realizing potential yield of turmeric. The 
results corroborate the earlier findings of Anjaneyulu and Krishnamurthy (1979), Ramachandran and Muthuswami (1984) and Amzad et al., (2005) who recorded markedly higher yield of turmeric when planted on broad bed furrow.

\section{Effect of irrigation levels on yield}

Irrigation levels produced significant effect on the total fresh rhizomes yield and yield of cured fingers of turmeric during individual years. Frequent irrigation recorded maximum total fresh rhizomes yield of turmeric (266.33, 317.69 and $292.01 \mathrm{q} \mathrm{ha}^{-1}$ ) and yield of cured fingers $\left(34.36,46.61\right.$ and $\left.40.48 \mathrm{q} \mathrm{ha}^{-1}\right)$ in irrigation level $40 \mathrm{~mm} \mathrm{CPE}$, compared to other irrigation level treatments (Table 1).

The yield of fresh mother rhizomes results are in accordance to those reported by Singh et al., (1998). Mahey et al., (1986) observed similar type of results wherein, irrigation scheduled at $40 \mathrm{~mm}$ evaporation rate produced maximum rhizome yield over its increasing evaporation rate scheduled, as the farmers practice with more frequent irrigations which puts optimum moisture in the root zone resulting in more rhizome yield.

\section{Effect of nutrient management on yield}

Treatments of nutrient management significantly influenced the total fresh rhizomes yield of turmeric and yield of cured fingers during the experimentation.

The highest total fresh rhizomes yield of turmeric $\left(250.49,300.57\right.$ and $275.53 \mathrm{q} \mathrm{ha}^{-1}$ ) and yield of cured fingers $(33.54,45.24$ and $39.39 \mathrm{q} \mathrm{ha}^{-1}$ ) were recorded with $100 \% \mathrm{RDF}+$ $25 \%$ RDN through vermicompost as compared to others treatments (Table 1).

Rao et al., (2005) and Velmurugan et al., (2007) have reported higher uptake of plant nutrients with the application of organic manures. The resultant increased photosynthates and their more preferential influx to the sink may be responsible for increased number and weight of mother and finger rhizomes per plant.

Mannikeri (2006) also reported increase in yield of turmeric when organic is used in combination with inorganic fertilizers. Majumdar et al., (2003) in ginger also recorded increase in yield due to application of vermicompost with inorganic fertilizers.

Singh (2015) recorded highest rhizome yield in treatment having $100 \%$ NPK + FYM + poultry manure + vermicompost + wheat straw in ginger. Application of organic manure in large quantity favours low water content and higher dry matter which is likely due to more accumulation of nutrients and total soluble solids due to multifarious positive effect of organic soil conditioner.

Higher dry rhizome recovery in turmeric with organic ammendments was also reported by Rao et al., (2005) and Sanwal et al., (2007). These results are in agreement with Majumdar et al., (2002), Manjunathgoud et al.,(2002), Kandiannan and Chandaragiri (2006), Krishnamoorthy et al., (2015) and Leva et al., (2013b).

\section{Interaction effect on yield}

The total fresh rhizomes yield of turmeric ha ${ }^{-1}$ $\left(327.13,384.29\right.$ and $\left.355.71 \mathrm{q} \mathrm{ha}^{-1}\right)$ and yield of cured fingers $\mathrm{ha}^{-1}(45.17,60.71$ and $52.94 \mathrm{q}$ ha $\left.{ }^{1}\right)$ were significantly more in treatment combination $\mathrm{I}_{1 \mathrm{x}} \mathrm{N}_{4}$ i.e. irrigation level $40 \mathrm{~mm}$ CPE with $100 \%$ RDF $+25 \%$ RDN through vermicompost over other treatment combinations during the study period (Table 2). Khan et al., (1999) reported that interaction of irrigation and nitrogen was significant in turmeric and recorded highest rhizome yield. 
Table.1 Yield and quality attributes influenced by land configuration, irrigation levels and nutrient management during 2014-15 and 2015-16.

\begin{tabular}{|c|c|c|c|c|c|c|c|c|c|c|c|c|c|c|c|}
\hline \multirow[t]{2}{*}{ Treatment / Year } & \multicolumn{3}{|c|}{$\begin{array}{l}\text { Total yield of turmeric } \\
\text { (Mother +Primary+ } \\
\text { Secondary Rhizomes) } \\
\left(\mathrm{q} \mathrm{ha} \mathbf{h}^{-1}\right)\end{array}$} & \multicolumn{3}{|c|}{$\begin{array}{l}\text { Yield of cured fingers } \\
\left(\mathrm{q} \mathbf{h a}^{-1}\right)\end{array}$} & \multicolumn{3}{|c|}{ Curcumin (\%) } & \multicolumn{3}{|c|}{ Oleoresin $(\%)$} & \multicolumn{3}{|c|}{ Curing (\%) } \\
\hline & $\begin{array}{l}2014- \\
2015\end{array}$ & $\begin{array}{l}2015- \\
2016\end{array}$ & $\begin{array}{l}\text { Pooled } \\
\text { mean }\end{array}$ & $\begin{array}{l}2014- \\
2015\end{array}$ & $\begin{array}{l}2015- \\
2016\end{array}$ & $\begin{array}{l}\text { Pooled } \\
\text { mean }\end{array}$ & $\begin{array}{l}2014- \\
2015\end{array}$ & $\begin{array}{l}2015- \\
2016\end{array}$ & $\begin{array}{l}\text { Pooled } \\
\text { mean }\end{array}$ & $\begin{array}{l}2014- \\
2015\end{array}$ & $\begin{array}{l}\text { 2015- } \\
2016\end{array}$ & $\begin{array}{l}\text { Pooled } \\
\text { mean }\end{array}$ & $\begin{array}{l}2014- \\
2015\end{array}$ & $\begin{array}{l}2015- \\
2016\end{array}$ & $\begin{array}{l}\text { Pooled } \\
\text { mean }\end{array}$ \\
\hline \multicolumn{16}{|l|}{ I) Main plot treatments } \\
\hline \multicolumn{16}{|l|}{ a) Land configuration } \\
\hline$L_{1}$ : Ridges and furrow & 204.61 & 244.14 & 224.38 & 26.81 & 35.36 & 31.08 & 5.38 & 5.55 & 5.47 & 7.32 & 7.86 & 7.59 & 18.34 & 20.36 & 19.35 \\
\hline $\mathbf{L}_{2}$ : Broad bed furrow & 227.43 & 270.93 & 249.18 & 30.08 & 40.20 & 35.14 & 5.39 & 5.57 & 5.48 & 7.33 & 7.91 & 7.62 & 18.84 & 20.97 & 19.90 \\
\hline S. E. $(\mathbf{m}) \pm$ & 2.03 & 2.74 & 1.91 & 0.57 & 0.87 & 0.58 & 0.03 & 0.02 & -- & 0.06 & 0.06 & -- & 0.24 & 0.30 & -- \\
\hline C. D. at $5 \%$ & 5.80 & 7.86 & 5.58 & 1.64 & 2.49 & 1.68 & NS & NS & -- & NS & NS & -- & NS & NS & -- \\
\hline \multicolumn{16}{|l|}{ b) Irrigation levels } \\
\hline$I_{1}: 40 \mathrm{~mm} \mathrm{CPE}$ & 266.33 & 317.69 & 292.01 & 34.36 & 46.61 & 40.48 & 5.45 & 5.65 & 5.55 & 7.48 & 8.08 & 7.78 & 19.59 & 21.73 & 20.66 \\
\hline$I_{2}: 60 \mathrm{~mm} \mathrm{CPE}$ & 220.80 & 261.86 & 241.33 & 29.39 & 38.44 & 33.92 & 5.42 & 5.56 & 5.49 & 7.24 & 7.98 & 7.61 & 18.61 & 20.53 & 19.57 \\
\hline$I_{3}: 80 \mathrm{~mm}$ CPE & 160.80 & 193.04 & 176.99 & 21.59 & 28.28 & 24.93 & 5.29 & 5.47 & 5.38 & 7.06 & 7.58 & 7.32 & 17.57 & 19.73 & 18.65 \\
\hline S. E. $(\mathbf{m}) \pm$ & 2.48 & 3.35 & 2.35 & 0.70 & 1.06 & 0.71 & 0.04 & 0.03 & -- & 0.08 & 0.07 & -- & 0.29 & 0.33 & -- \\
\hline C. D. at 5\% & 8.00 & 9.61 & 6.83 & 2.01 & 3.04 & 2.06 & 0.11 & 0.08 & -- & 0.22 & 0.20 & -- & 0.83 & 0.94 & -- \\
\hline \multicolumn{16}{|l|}{ II) Sub plot treatments } \\
\hline \multicolumn{16}{|l|}{ c) Nutrient management } \\
\hline $\begin{array}{l}\mathrm{N}_{1}: 100 \% \text { RDF } \quad(200: 100: 100 \\
\text { NPK kg/ha) }\end{array}$ & 203.64 & 239.48 & 221.56 & 26.80 & 35.00 & 31.00 & 5.26 & 5.42 & 5.34 & 7.17 & 7.69 & 7.43 & 18.18 & 20.14 & 19.16 \\
\hline $\begin{array}{l}\mathrm{N}_{2}: 75 \% \text { RDF }+25 \% \text { RDN } \\
\text { through vermicompost }\end{array}$ & 183.96 & 220.42 & 202.19 & 24.99 & 32.57 & 28.78 & 5.42 & 5.57 & 5.50 & 7.35 & 8.01 & 7.68 & 18.33 & 20.38 & 19.35 \\
\hline $\mathrm{N}_{3}: 125 \%$ RDF & 226.00 & 269.66 & 247.83 & 28.46 & 38.10 & 33.28 & 5.30 & 5.52 & 5.41 & 7.23 & 7.72 & 7.47 & 18.30 & 20.58 & 19.44 \\
\hline $\begin{array}{l}\mathrm{N}_{4}: 100 \% \text { RDF }+25 \% \text { RDN } \\
\text { through vermicompost. }\end{array}$ & 250.49 & 300.57 & 275.53 & 33.54 & 45.24 & 39.39 & 5.57 & 5.72 & 5.64 & 7.55 & 8.12 & 7.84 & 19.55 & 21.56 & 20.55 \\
\hline S. E. $(\mathbf{m}) \pm$ & 3.51 & 3.77 & 2.56 & 0.76 & 1.15 & 0.66 & 0.07 & 0.06 & -- & 0.09 & 0.09 & -- & 0.34 & 0.37 & -- \\
\hline C. D. at $5 \%$ & 10.03 & 10.82 & 7.18 & 2.19 & 3.31 & 1.85 & 0.21 & 0.17 & -- & 0.26 & 0.25 & -- & 0.97 & 0.96 & -- \\
\hline \multicolumn{16}{|l|}{ Interaction effect } \\
\hline \multicolumn{16}{|l|}{ L x I } \\
\hline S. E. $(\mathrm{m}) \pm$ & 3.51 & 4.73 & 3.31 & 0.99 & 1.50 & 1.00 & 0.053 & 0.036 & -- & 0.110 & 0.101 & -- & 0.408 & 0.520 & -- \\
\hline C. D. at $5 \%$ & NS & NS & NS & NS & NS & NS & NS & NS & -- & NS & NS & -- & NS & NS & NS \\
\hline \multicolumn{16}{|l|}{$L \times N$} \\
\hline S. E. $(\mathrm{m}) \pm$ & 4.95 & 5.33 & 3.61 & 1.07 & 1.62 & 0.93 & 0.102 & 0.091 & -- & 0.134 & 0.125 & -- & 0.476 & 0.473 & -- \\
\hline C. D. at $5 \%$ & NS & NS & NS & NS & NS & NS & NS & NS & -- & NS & NS & -- & NS & NS & NS \\
\hline \multicolumn{16}{|l|}{ I $\times \mathbf{N}$} \\
\hline S. E. $(\mathrm{m}) \pm$ & 6.07 & 6.53 & 4.42 & 1.32 & 1.99 & 1.13 & 0.125 & 0.111 & -- & 0.164 & 0.153 & -- & 0.583 & 0.579 & -- \\
\hline C. D. at $5 \%$ & 17.41 & 18.74 & 12.43 & 3.79 & 5.72 & 3.20 & NS & NS & -- & NS & NS & -- & 1.67 & 1.66 & -- \\
\hline \multicolumn{16}{|l|}{$L \times I \times N$} \\
\hline S. E. $(\mathrm{m}) \pm$ & 8.58 & 9.24 & 6.26 & 1.86 & 2.82 & 4.52 & 0.176 & 0.158 & -- & 0.232 & 0.216 & -- & 0.825 & 0.819 & -- \\
\hline C. D. at $5 \%$ & NS & NS & NS & NS & NS & NS & NS & NS & -- & NS & NS & -- & NS & NS & NS \\
\hline GM & 216.02 & 257.53 & 236.78 & 28.45 & 37.78 & 33.11 & 5.39 & 5.56 & -- & 7.32 & 7.88 & -- & 18.59 & 20.66 & -- \\
\hline
\end{tabular}


Table.2 Yield attributes and curing (\%) as influenced by irrigation levels and nutrient management during 2014-15 and 2015-16.

\begin{tabular}{|c|c|c|c|c|c|c|c|c|c|c|c|c|}
\hline \multirow{3}{*}{$\begin{array}{l}\text { Irrigation levels } \\
\text { / } \\
\text { Nutrient } \\
\text { management }\end{array}$} & \multicolumn{4}{|c|}{$\begin{array}{l}\text { Total fresh rhizomes yield of turmeric } h^{-1} \\
\text { (q) }\end{array}$} & \multicolumn{4}{|c|}{ Yield of cured fingers $\mathrm{ha}^{-1}(\mathrm{q})$} & \multicolumn{4}{|c|}{ Curing (\%) } \\
\hline & $\mathbf{N}_{1}$ & $\mathbf{N}_{2}$ & $\mathbf{N}_{3}$ & $\mathbf{N}_{4}$ & $\mathbf{N}_{1}$ & $\mathbf{N}_{2}$ & $\mathbf{N}_{3}$ & $\mathbf{N}_{4}$ & $\mathbf{N}_{1}$ & $\mathbf{N}_{2}$ & $\mathbf{N}_{3}$ & $\mathbf{N}_{4}$ \\
\hline & \multicolumn{4}{|c|}{ 2014-2015 } & \multicolumn{4}{|c|}{ 2014-2015 } & \multicolumn{4}{|c|}{ 2014-2015 } \\
\hline$I_{1}: 40$ mm CPE & 244.86 & 215.09 & 278.24 & 327.13 & 30.99 & 28.32 & 32.96 & 45.17 & 18.78 & 18.08 & 19.02 & 22.48 \\
\hline$I_{2}: 60$ mm CPE & 209.86 & 186.59 & 235.74 & 251.00 & 28.43 & 26.33 & 30.13 & 32.67 & 18.62 & 17.84 & 18.85 & 19.14 \\
\hline$I_{3}: 80$ mm CPE & 156.19 & 150.20 & 164.03 & 173.34 & 20.98 & 20.31 & 22.28 & 22.77 & 17.50 & 17.33 & 17.67 & 17.77 \\
\hline S. E. (m) \pm & \multicolumn{4}{|l|}{6.07} & \multicolumn{4}{|l|}{1.32} & \multicolumn{4}{|l|}{0.58} \\
\hline C. D. at $5 \%$ & \multicolumn{4}{|l|}{17.41} & \multicolumn{4}{|l|}{3.79} & \multicolumn{4}{|l|}{1.67} \\
\hline & \multicolumn{4}{|c|}{ 2015-16 } & \multicolumn{4}{|c|}{ 2015-16 } & \multicolumn{4}{|c|}{ 2015-16 } \\
\hline$I_{1}: 40$ mm CPE & 291.09 & 252.20 & 343.19 & 384.29 & 42.61 & 36.91 & 46.20 & 60.71 & 20.66 & 20.23 & 21.54 & 22.69 \\
\hline$I_{2}: 60$ mm CPE & 244.70 & 225.32 & 275.61 & 301.84 & 36.47 & 34.70 & 39.09 & 43.51 & 20.51 & 19.99 & 20.34 & 21.10 \\
\hline $\mathrm{I}_{3}: 80 \mathrm{~mm}$ CPE & 182.65 & 183.74 & 190.19 & 215.59 & 26.51 & 26.09 & 29.01 & 31.50 & 19.48 & 19.09 & 19.82 & 20.54 \\
\hline S. E. (m) \pm & \multicolumn{4}{|l|}{6.53} & \multicolumn{4}{|l|}{1.99} & \multicolumn{4}{|l|}{0.57} \\
\hline \multirow[t]{2}{*}{ C. D. at $5 \%$} & \multicolumn{4}{|l|}{18.74} & \multicolumn{4}{|l|}{5.72} & \multicolumn{4}{|l|}{1.66} \\
\hline & \multicolumn{4}{|c|}{ Pooled mean } & \multicolumn{4}{|c|}{ Pooled mean } & & & & \\
\hline $\mathrm{I}_{1}: 40 \mathrm{~mm}$ CPE & 267.98 & 233.64 & 310.72 & 355.71 & 36.80 & 32.62 & 39.58 & 52.94 & & & & \\
\hline$I_{2}: 60$ mm CPE & 227.28 & 205.95 & 255.67 & 276.42 & 32.45 & 30.52 & 34.61 & 38.09 & & & & \\
\hline$I_{3}: 80 \mathrm{~mm} \mathrm{CPE}$ & 169.42 & 166.97 & 177.11 & 194.47 & 23.75 & 23.20 & 25.65 & 27.13 & & & & \\
\hline S. E. (m) \pm & \multicolumn{4}{|l|}{4.42} & \multicolumn{4}{|l|}{1.13} & & & & \\
\hline C. D. at $5 \%$ & \multicolumn{4}{|l|}{12.43} & \multicolumn{4}{|l|}{3.23} & & & & \\
\hline
\end{tabular}

$\mathrm{N}_{1}: 100 \%$ RDF (200:100:100 NPK kg/ha), $\mathrm{N}_{2}: 75 \%$ RDF +25\% RDN through vermicompost, $\mathrm{N}_{3}: 125 \%$ RDF and $\mathrm{N}_{4}: 100 \%$ RDF $+25 \%$ RDN through vermicompost. 
The results of total fresh rhizomes yield of turmeric are in accordance with the findings of Rathod (2010), Anonymous, 2013, Tripathi et al., (2014) and Samir Bhatti et al., (2019). The yield of cured fingers results are in agreement with Tripathi et al., (2014) and Sandeep Kumar Tripathi et al., (2019).

Effect of land configuration on quality of turmeric

The effect of different treatments of land configuration on curcumin, oleoresin content and dry rhizome recovery percentage of turmeric was found to be non-significant. Numerically broad bed furrow planting recorded higher mean curcumin content $(5.48 \%)$, oleoresin content $(7.62 \%)$ and dry rhizome recovery $(19.90 \%)$ over the ridges and furrow method of planting. Similar type of results was observed by Ramachandran and Muthuswami (1984) and Kaur (2001) in turmeric. Similar results were also reported by Khan and Agarwal (1985) and Kumar and Gill (2009) in turmeric. Khan and Agarwal (1985) and Raghavaiah et al., (1992) also reported that land configuration treatments had no significant effect on quality parameters of crops tested.

\section{Effect of irrigation levels on quality of turmeric}

There were significant differences in the curcumin, oleoresin content and dry rhizome recovery percentage among different irrigation levels. Data presented in table 1 on irrigation levels revealed that curcumin, oleoresin content and dry rhizome recovery percentage significantly influenced due to different irrigation levels during both the years. The highest mean curcumin content (5.55\%), oleoresin content $(7.78 \%)$ and dry rhizome recovery $(20.66 \%)$ was recorded by treatment $40 \mathrm{~mm}$ CPE over the other treatments (Table 1).
These results are in conformity with Mohamed et al., (2014), Amirjani. (2013) and Tripathi Sandeep et al., (2015) and reported that curcumin in dry rhizomes increased when the plants irrigated every week compared to irrigation treatments every two or three weeks. The results of oleoresin corroborate the earlier findings of Hassan and Ali (2013) and Tripathi Sandeep et al., (2015). The present findings of dry rhizome recovery percentage are in consonance with Mohamed et al., (2014).

\section{Effect of nutrient management on quality of turmeric}

Treatments of nutrient management significantly influenced the curcumin, oleoresin content and curing percentage during the experimentation. Higher curcumin content $(5.64 \%)$, oleoresin content $(7.84 \%)$ and curing percentage (20.55) was recorded with $100 \%$ RDF $+25 \%$ RDN through vermicompost which was significantly superior over the other treatments. Rao (2000) reported that curcumin content was more in organic and inorganic combinations over recommended doses of fertilizer alone. Similar results are in conformity with Manhas and Gill (2012) for oleoresin content in turmeric. Similar results are also in line with scientist Manhas and Gill (2012) and Karthikeyan (2009) for curing percentage in turmeric.

\section{Interaction effect on quality of turmeric}

Interaction effects were found to be nonsignificant during both the years of experimentation for curcumin and oleoresin content where as dry rhizome recovery percentage were recorded significantly higher in treatment combination $\mathrm{I}_{1} \mathrm{XN}_{4}$ i.e. irrigation level $40 \mathrm{~mm} \mathrm{CPE}$ with $100 \% \mathrm{RDF}+25 \%$ RDN through vermicompost (22.48 and $22.69 \%$ ) over other treatment combinations during the experimentation respectively. 
Based on the findings of two years investigation, it can be concluded that for higher yield, curcumin, oleoresin and curing percentage from turmeric (var. PDKVWaigaon) can be secured by planting on broad bed furrow with irrigation level of $40 \mathrm{~mm}$ $\mathrm{CPE}$ and application of $100 \% \mathrm{RDF}+25 \%$ RDN through vermicompost in heavy black (clay) soil of Vidarbha region under irrigated condition.

\section{References}

Amirjani M. R. (2013) Effects of drought stress on the alkaloid contents and growth parameters of Catharanthus roseus. ARPN J. Agric. Bio. Sci., 8 (11): 745-750

Amzad Hossain, Yukio Ishimine, Keiji Motomura and Hikaru Akamine (2005) Effects of planting pattern and planting distance on growth and yield of turmeric (Curcuma longa L.). Plant Prod. Sci., 8 (1): 95-105

Anjaneyulu V. S. R. and Krishnamurthy D.(1979) The efficacy of broad ridge method of planting turmeric. Indian Arecanut, Spices and Cocoa J., 2 (4) : 116-118

Anonymous $\left(2013^{\mathrm{a}}\right)$ All India Coordinated Research Project on Water Management, Directorate of water management. Annual report (2012 - 2013), Bhubaneswar : pp 78

Gill B. S., Singh A., Devinder Singh, Gandhi N. and Jaspreet Kaur (2009) Growth and yield of turmeric (Curcuma longa L.) intercropped in poplar (Populus deltoides Bartram ex Marshall) plantation at Punjab. J. Spices and Aromatic Crops, 18 (1) : 40-42

Jayapaul P., Udayakumar B.,Devasagayam M. M., Pandian B. J., Palchamy A. and Balkrishnan A. (1996) Effect of land configuration methods, irrigation regimes and soil moisture conservation amendments on soybean (Glycine max (L.) Merr.) yield and quality characters. Crop Res., 10 (3) : 253-257

Jayashree G. and Rao, N. (2002) Effect of different long term management practices on microstructure of Vertisols and Alfisols. J. Indian Soc. Soil Sci., 50 (3) : 452-456

Kandiannan K. and Chandaragir K. K. (2006) Influence of varieties, dates of planting, spacing and nitrogen levels on growth, yield and quality of turmeric (Curcuma longa). Indian J. Agric. Sci., 76 (7) : 432434

Karthikeyan P.K., Ravichandran M., Imas P. and Assaraf M. (2009) The effect of potassium on the yield and quality of turmeric (Curcuma longa).International Potash Institute, Horgen, Switzerland. No. 21

Kaur S. (2001) Effect of spacing and farmyard manure levels on growth and yield of flat and ridge planted turmeric. M.Sc Thesis, Punjab Agricultural University, Ludhiana

Khan G. M. and Agarwal S. K.(1985) Effect of moisture stress, sowing methods and nitrogen levels on the quality and oil yield of mustard. HAU J. Res., 15 (1) : 82-86

Khan M. M and Shivashankar K., Krishna Manohar R., Sree Rama R and Kasiyanna (1999) Fertigation in horticultural crops. In: Proc. Advances in Micro Irrigation and Fertigation, June 21-30, Dharwad. pp: 181-197

Krishnamoorthy C., Soorianathasundaram K. and Mekala S.(2015) Effect of fertigation on fue, quality and economics of cultivation in turmeric (Curcuma longa L.) cv. BSR 2. International Journal of Agricultural Science and Research, 5 (1) : 67-72

Kumar B. and Gill B. S. (2009) Effect of method of planting and harvesting time on growth, yield and quality of turmeric (Curcuma longa L.). J. Spices Arom. 
Crops, 18 (1) : 22-27

Leva R. L., Thanki J. D., Patel D. D and Patel T. U.(2013) Growth and yield of turmeric (Curcuma longa L.) as influenced by planting methods and fertigation under vertisols of South Gujarat condition. Research on Crops, 14 (3): 964-967

Mahey R. K., Randhwa G. S and Gill S. R. S. (1986) Effect of irrigation and mulching on water conservation, growth and yield of turmeric. Indian Journal of Agronomy, 31 (1): 79-82

Majumdar B., Venkatesh M. S. and Kumar K.(2002) Effect of nitrogen and farmyard manure on yield and nutrient uptake of turmeric (Curcuma longa) and different forms of inorganic $\mathrm{N}$ build-up in an acidic Alfisol of Meghalaya. Indian $\mathrm{J}$. Agril. Sci., 72 (9) : 528-531

Majumdar B., Venkatesh M.S., Kailash Kumar and Patiram (2003) Effect of N levels, FYM and mother rhizome removal on yield, nutrient uptake and quality of ginger (Zingiber officinale Rosc.) and different forms of $\mathrm{N}$ build up in an acidic Alfisol of Meghalaya. Crop Res. 25 (3) : $478-483$

Manhas S.S. and Gill B.S.(2012) Effect of different cultural practices of turmeric (Curcuma longa) in Punjab. Journal of Spices and Aromatic crops, 21(1): 53-58

Manjunath M. N., Sattigeri V. D. and Nagaraja K. V. (1991) Curcumin in turmeric. Indian Spices, March : 7-9

Manjunathgoud B., Venkatesha J. and Bhagavantagoudra K.H.(2002) Studies on plant density and levels of NPK on growth, yield and quality of turmeric cv. Bangalore local. Mysore Journal of Agricultural Research, 36:31-35

Mannikeri.I. M. (2006) Studies on production technology of Turmeric. (Curcuma longa L.). Ph. D. Thesis. Department of Horticulture,University of Agriculture Sciences, Dharwad, Karnataka state,
India

Medhi G. and Bora P.(1993) Effect of nitrogen and spacing on growth and yield of turmeric. Haryana J.Horticultural Sci., 22: 253-255

Mohamed M A, Wahba H E, Ibrahim M E, Yousef A A.(2014) Effect of irrigation intervals on growth and chemical composition of some Curcuma spp. plants. Nusantara Bioscience, 6 : 140145.

Panse V.G. and Sukhtame P.V.(1985) Statistical methods for agricultural workers. ICAR, New Delhi

Purseglove J. W., Brown F. G., Green C. L. and Robbins S. R. J. (1981) Turmeric in spices. Longman Green, London and New York, 539-540

Raghavaiah C. V., Krishnamurthy S., Athinarayanan R. and Sharma C. B.(1992)Effect of method of irrigation on yield and quality of cigarfiller tobacco (Nicotiana tabacum). Indian J. Agril. Sci., 62 (2) : 16-19

Ramachandran M. and Muthuswami S. (1984) Studies on the influence of method of planting and spacing on yield and quality of turmeric (Curcuma longa L.). South Indian Hort., 32 (3) : 143-145

Ranganna S.(1986) Handbook of analysis and quality control for fruits and vegetable products. 2nd edition. pp : 2

Rao A. M., Rao P. V., Reddy Y. N. and Reddy M. S. N. (2005) Effect of organic and inorganic manurial combinations on growh, yield and quality of turmeric (Curcuma longa L.). J. Plantation Crops, 33 (3) : 198-205

Rathod S. D., Kamble B. M and Pawar V. P.(2010) Effect of irrigation and levels of fertilizer on yield of turmeric in vertisols irrigated through micro sprinkler. Advances in Plant Sciences, 23 (1) : 201203

Ruby AJ, Kuttan G, Dinesh BK (1995) Antitumour and antioxidant activity of natural 
curcuminoids. Cancer Lett, 94 : 79-83

Samir Bhatti J.C. Sharma and Ridham Kakar (2019) Effect of Irrigation and Nitrogen Levels on Nutrient Uptake, Water Use Efficiency and Productivity of Onion (Allium cepa L.) in Himachal Pradesh. Int.J.Curr.Microbiol.App.Sci. 8 (2): 398408

Sandeep Kumar Tripathi, Babloo Sharma, R. Ray, Monika Devi and P.Mishra (2019) Studies on growth and yield of turmeric under different irrigation and nutrient management strategies at West Bengal. Bulletin of Environment, Pharmacology and Life Sciences Bull. Env. Pharmacol. Life Sci., 8 (6) : 14-20

Sanwal S. K., Laxminarayana K., Yadav R. K., Rai N., Yadav D. S. and Bhuyan, M. (2007) Effect of organic manures on soil fertility, growth, physiology, yield and quality of turmeric. Indian J. Hort., 64 (4): $444-449$

Shishodia S. (2005) Modulation of transcription factors by curcumin.Adv. Exp. Biol. 595,127-148

Singh, V.B., N.P. Singh and B. Swer. (1998) Effect of potassium and nitrogen on yield and quality of turmeric (Curcuma longa).
J. Potassium Res., 15 (1/4) : 88-92

Singh S.P.(2015) Nutrient supplementation through organic manures for growth and yield of ginger (Zingiber officinale Rose.) Journal of Eco-friendly Agriculture, 10 (1): 28-31

Tripathi S. K., Ray R., Patra S. K. (2014) Effect of irrigation and nutrient levels on growth, yield attributes and yield of turmeric (Curcuma longa L.) under alluvial soils of West Bengal. Environment and Ecology, 32, (3A) : 1096 - 1099

Tripathi Sandeep,Sharma Babloo, Meena Santosh, Ray Rapti and Patra,Sanmay (2015) Influence of Irrigation Schedules and Nutrient Sources on Yield, Quality, Water Use and Water Productivity of Turmeric under Alluvial Soils of West Bengal. Journal of Pure and Applied Microbiology, 9 : 3109-3114

Velmurugan M., Chezhiyan N. and Jawaharlal M. (2007) Studies on the effect of organic manures and biofertilizers on rhizome yield and its attributes of turmeric cv. BSR-2. Asian J. Hort., 2 (2) : 23-29

\section{How to cite this article:}

Dikey, H. H., V. M. Bhale, V. S. Kale and Wankhade, R. S. 2019. Influence of Land Configuration, Irrigation Level and Nutrient Management on Yield and Quality of Turmeric . Int.J.Curr.Microbiol.App.Sci. 8(09): 2296-2305. doi: https://doi.org/10.20546/ijcmas.2019.809.265 